\title{
Cluster and Factor Analysis of Elements in Serum and Urine of Diabetic Patients with Peripheral Neuropathy and Healthy People
}

\author{
Wenjia Guo $^{1} \cdot$ Qi Zhou $^{2} \cdot$ Yanan Jia $^{1} \cdot$ Jiancheng Xu ${ }^{1}$ (]
}

Received: 3 April 2019 / Accepted: 3 May 2019 / Published online: 28 May 2019

(C) The Author(s) 2019

\begin{abstract}
Diabetic peripheral neuropathy (DPN) is a common complication of diabetes mellitus, presented as a major teratogenic cause worldwide. This study discussed alternation and correlation of magnesium $(\mathrm{Mg})$, calcium $(\mathrm{Ca})$, copper $(\mathrm{Cu})$, zinc $(\mathrm{Zn})$, iron $(\mathrm{Fe})$, chromium (Cr), and selenium (Se) among DPN patients and healthy people using multivariate statistical analysis. Fifty patients with DPN were recruited from endocrinology department, First Hospital of Jilin University between January 2010 and October 2011 and also 50 healthy subjects were enrolled at the same time. Inductively coupled plasma mass spectrometry (ICP-MS) was used to assay elements in serum and urine. Cluster analysis was used to clarify alternation of elements' homogeneity. Factor analysis was performed to evaluate the most informative kinds of elements. $\mathrm{Mg}, \mathrm{Ca}, \mathrm{Zn}$, and $\mathrm{Cr}$ in DPN patients were significantly lower in serum whereas significantly higher in urine. Elements were clustered into 4 or 5 clusters based on internal association using between-groups linkage algorithm. Serum $\mathrm{Cr}$, Se, and $\mathrm{Fe}$ were grouped, and $\mathrm{Mg}$ related to Ca more closely in both serum and urine in DPN. Factor analysis revealed discrepancies of elements' contribution. Cr, Se, and Fe appeared to be the most crucial factors contributing to DPN. $\mathrm{Mg}, \mathrm{Ca}, \mathrm{Zn}$, and $\mathrm{Cu}$ were more influential, whereas $\mathrm{Cr}$ became less potent to disease. Contributed value of elements could be determined and specified using loadings in scree plot. Future studies and delicate statistical models should be applied.
\end{abstract}

Keywords Elements $\cdot$ Diabetic peripheral neuropathy $\cdot$ Multivariate analysis $\cdot$ Factor analysis $\cdot$ Cluster analysis

\section{Introduction}

Diabetic peripheral neuropathy (DPN) is a common complication of diabetes mellitus [1], and about $50 \%$ patients are suffering from it $[2,3]$. Some scholars predict that $10 \%$ or so newly diagnosed diabetes patients are with DPN [4], disorders presented as the major teratogenic cause worldwide [5]. Besides symptoms such as pain and sensory deprivation, patients with DPN may suffer from ulcers at the extremities [6, 7]. It is a primary cause of amputation among the diabetic population [6] and damages their quality of life consequently.

Recent studies have confirmed that disturbed element metabolism under glucose disorders interact with diabetes progression, complication occurrence, and vice versa [7].

Jiancheng Xu

jianchengxu@yeah.net

1 Department of Laboratory Medicine, First Hospital of Jilin University, Changchun, China

2 Department of Pediatrics, First Hospital of Jilin University, Changchun, China
Different status as prediabetes, different types and diverse complications exert unlike changes of elements $[8,9]$. Elements relate to each other closely [10], and it is very likely that information be missing or even misbelieved when dissociate just one of them. Therefore, classification methods could aggregate certain elements which contain similar information and, meanwhile, identify some of the most effective ones that may efficiently refine content and be time and cost saving.

It is stated that many elements alter homeostasis through various mechanisms. Ca affects insulin secretion of $\beta$-cells, and elevation of intracellular calcium promotes type 2 diabetes mellitus complications [11]. Mg is a key cofactor for many enzymes in carbohydrate metabolism and improves insulin resistance [12]. High concentration of Fe damages pancreatic $\beta$-cells [13]. Se prevents diabetes complications by seleniumdependent glutathione peroxidase and other selenoproteins involved in antioxidant system [14]. Except being essential for carbohydrate metabolism, $\mathrm{Cr}$ is cofactor for insulin action as well and helps to maintain glucose homeostasis [15]. Zn participates in signaling of insulin receptor initiation and regulation of its synthesis [16]. Cu has insulin-like activity and promotes lipogenesis [17]. 
The purpose of this study is to compare $\mathrm{Mg}, \mathrm{Ca}, \mathrm{Cu}, \mathrm{Zn}$, $\mathrm{Se}, \mathrm{Cr}$, and Fe levels between DPN patients and healthy ones, which are the most studied and "powerful" ones [18]. Cluster analysis is used to classify elements, and elements with greater potency are observed in factor analysis. Previous research of our group [8, 9] found and proved these substances altered in both blood and urine, supposing that their metabolic rate and mode were different in diabetes. Thus, we conduct this experiment of two fluids. We investigated imbalance characteristics of elements in serum and urine of patients with DPN using cluster analysis and factor analysis.

\section{Materials and Methods}

\section{Subjects}

This experiment was based on previous studies [8]. In brief, 50 patients with DPN (29 males and 21 females, ages range of $27-$ 79 with median age of 56 years old, duration of diabetes $7 \pm$ 2.5 years, BMI $21.56 \pm 3.65 \mathrm{~kg} / \mathrm{m}^{2}$, serum glucose $9.40 \pm$ $3.31 \mathrm{mmol} / \mathrm{L}$, hemoglobin $\mathrm{A}_{1 \mathrm{c}} 8.06 \pm 1.68 \%$ ) were enrolled to endocrinology department of the First Hospital of Jilin University from January 2010 to October 2011, and 50 healthy subjects (31 males and 19 females, ages of 20-59 years old with median age of 50 years old, BMI $25.03 \pm 3.07 \mathrm{~kg} / \mathrm{m}^{2}$, serum glucose $4.62 \pm 1.23 \mathrm{mmol} / \mathrm{L}$, hemoglobin $\mathrm{A}_{1 \mathrm{c}} 4.15 \pm 1.24 \%$ ) were examined and tracked due to their electrical record in the same period. All participants had signed the informed statement. DPN patients were affirmed that not taking element supplementation and vitamins. Their liquid intake was approximately 2000 $\pm 500 \mathrm{ml}$, including 250 500 $\mathrm{ml}$ intravenous injection drugs, $250 \mathrm{ml}$ sugar-free milk, 500 1000 g vegetables, and drinking water. Their baseline characteristics were detailed described and adjusted by covariance analysis to control confounding factors. The selection criteria were based on reliable diagnosis from electronic medical record. The diagnostic standard referred to Diagnostic criteria for diabetic peripheral neuropathy by Chinese Doctor Association (2009) [19]: (1) detailed history and of diabetes; (2) signs and symptoms: distal symmetric polyneuropathy, focal mononeuropathy, asymmetric multiple focal neuropathy, multiple radiculopathy, and autonomic neuropathy. This study was approved by the institutional ethics committee of the First Hospital of Jilin University (2009-004) and conformed to the provisions of the Declaration of Helsinki.

\section{Measurement}

The procedure was standardized, the same as previous experiments [8, 20, 21]. Blood and morning urine samples obtained from subjects were taken after fasting for at least $8 \mathrm{~h}$ into special metal-free tubes (pre-soaked in $20 \% \mathrm{v} / \mathrm{v}$ nitric acid, $72 \mathrm{~h}$ ) for analysis of elements. Separated serum was preserved; $10 \mathrm{ml}$ urine was conserved from each urine sample. All samples were frozen at $-80{ }^{\circ} \mathrm{C}$ before detection. Inductively coupled plasma mass spectrometry (ICP-MS) was performed by an experienced technician for determination of $\mathrm{Mg}, \mathrm{Ca}, \mathrm{Cu}, \mathrm{Zn}, \mathrm{Fe}, \mathrm{Cr}$, and $\mathrm{Se}$ in serum and urine. Quality control of samples was conducted with standard reference materials from China standard Material Center. Limits of detection were $1.0 \mu \mathrm{g} / \mathrm{L}$ for $\mathrm{Cr}, \mathrm{Fe}, \mathrm{Cu}, \mathrm{Zn}$, and Se while $10.0 \mu \mathrm{g} / \mathrm{L}$ for $\mathrm{Mg}$ and $\mathrm{Ca}$. Recovery of standard trace elements (accuracy) ranged from 93.0 to $98.9 \%$.

\section{Statistical Analysis}

Shapiro-Wilk test was performed on continuous data to determine normality. Mean \pm standard deviation $(\bar{x} \pm \mathrm{s})$ or median (percentile) $\left[M\left(\mathrm{P}_{25} \sim \mathrm{P}_{75}\right)\right]$ was selected for description. Comparison between groups was performed applying independent sample $t$ test or Mann-Whitey $U$ test. Pearson correlation was used for the linear dependence between two continuous variables, and the Spearman correlation was chosen for nonparametric measure of association between two variables.

Hierarchical cluster analysis was adopted after using the $Z$ score method for data process. The correlation coefficient is compared by between-groups linkage algorithm, displaying as dendrogram. The interpretation of the diagram can be determined by cluster number based on discrepancy among categories and logical explanation. For clear observation, a line could be drawn at the extent for classification of selected cluster and corresponding variables under this category on axis. The smaller the value on the vertical axis as parting, the higher homogeneity variables own [10]. Detailed theory refers to production [22-24].

Table 1 Comparison of element concentrations in serum and urine between control and DPN patients

\begin{tabular}{llll}
\hline & $\mathrm{CON}(n=50)$ & $\mathrm{DPN}(n=50)$ & $p$ \\
\hline $\mathrm{Mg}(\mathrm{mg} / \mathrm{L})$ & $35.71(30.78 \sim 39.72)$ & $21.62(15.81 \sim 28.63)$ & $<0.001^{*}$ \\
$\mathrm{UMg}(\mathrm{mg} / \mathrm{L})$ & $34.37 \pm 22.45$ & $61.09 \pm 20.70$ & $<0.001^{*}$ \\
$\mathrm{Ca}(\mathrm{mg} / \mathrm{L})$ & $164.95(145.83 \sim 177.22)$ & $92.57 \pm 40.93$ & $<0.001^{*}$ \\
$\mathrm{UCa}(\mathrm{mg} / \mathrm{L})$ & $62.04 \pm 36.73$ & $95.50 \pm 49.78$ & $<0.001^{*}$ \\
$\mathrm{Cu}(\mathrm{mg} / \mathrm{L})$ & $0.844 \pm 0.159$ & $1.129 \pm 0.260$ & $<0.001^{*}$ \\
$\mathrm{UCu}(\mathrm{mg} / \mathrm{L})$ & $0.029 \pm 0.008$ & $0.033 \pm 0.010$ & 0.066 \\
$\mathrm{Zn}(\mathrm{mg} / \mathrm{L})$ & $0.803 \pm 0.124$ & $0.646 \pm 0.114$ & $<0.001^{*}$ \\
$\mathrm{UZn}(\mathrm{mg} / \mathrm{L})$ & $0.240 \pm 0.102$ & $0.553 \pm 0.140$ & $<0.001^{*}$ \\
$\mathrm{Cr}(\mathrm{mg} / \mathrm{L})$ & $0.185(0.136 \sim 0.221)$ & $0.135(0.073 \sim 0.173)$ & $0.001^{*}$ \\
$\mathrm{UCr}(\mathrm{mg} / \mathrm{L})$ & $0.034(0.024 \sim 0.041)$ & $0.046 \pm 0.025$ & $0.005^{*}$ \\
$\mathrm{Fe}(\mathrm{mg} / \mathrm{L})$ & $1.167(1.402 \sim 2.185)$ & $1.841(1.147 \sim 2.409)$ & 0.923 \\
$\mathrm{UFe}(\mathrm{mg} / \mathrm{L})$ & $0.410 \pm 0.239$ & $0.491 \pm 0.330$ & 0.138 \\
$\mathrm{Se}(\mathrm{mg} / \mathrm{L})$ & $0.067(0.056 \sim 0.084)$ & $0.064(0.046 \sim 0.090)$ & 0.363 \\
$\mathrm{USe}(\mathrm{mg} / \mathrm{L})$ & $0.017(0.012 \sim 0.023)$ & $0.014 \pm 0.008$ & 0.083 \\
\hline
\end{tabular}

$* p<0.05$, there is statistically significant difference 


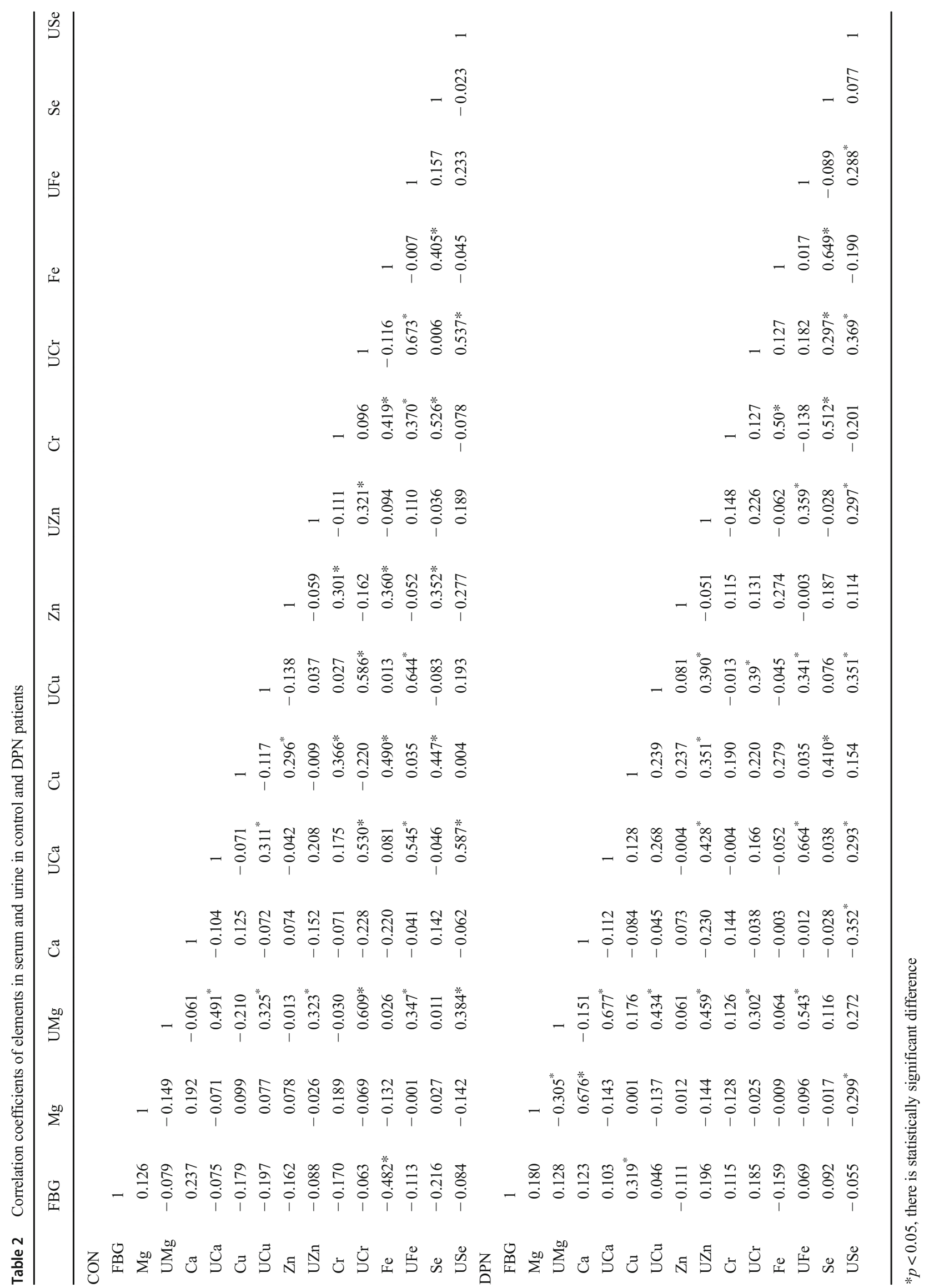


KMO and Bartlett's spherical test were performed to evaluate applicability of factor analysis on condition of $\mathrm{KMO}$ value $>0.5$ and Bartlett test $p<0.05$. The first three factors are extracted after rotating with maximum variance method. Loadings were calculated and scree plots were drawn. Scree plot is a useful figure in geology, the horizontal axis stands for factors, and the vertical axis shows eigenvalue. The eigenvalue, representing information equal to how many variables have explained, is regarded as a measurement of factors' weight. Each point means eigenvalue of corresponding factor. Proportion of containing information of the first three factors is indicated.

Statistical analysis and graphing were completed using SPSS 24.0.

\section{Results}

\section{Comparison of Elements Concentration in Serum and Urine Between Control and DPN Group}

As shown in Table 1, except urinary copper (UCu), serum Fe, urinary iron (UFe), serum Se, and urinary selenium (USe), other indicators had shown significant differences between two groups. The levels of $\mathrm{Mg}, \mathrm{Ca}, \mathrm{Zn}$, and $\mathrm{Cr}$ in serum of DPN patients were significantly lower than those of control $(p<0.05)$, while these elements in urine as well as serum $\mathrm{Cu}$ concentration were significantly higher in control $(p<0.05)$.

\section{Correlation Analysis of Element Concentrations in Serum and Urine in Control and DPN Group}

An important requirement for factor analysis application is multicollinearity among variables, i.e., relationship to each other in certain way. The closer relationship variables present, the better the dimension reduction effect is. Table 2 showed that there was correlation between elements in serum and urine. Besides, whether the correlation was statistically significant and coefficients had changed under the DPN group.

\section{Cluster Analysis of Element Concentrations in Serum and Urine in Control and DPN Group}

Figure $1 \mathrm{a}, \mathrm{b}$, and c were grouped into 4 clusters with Fig. 1d into 5 at 10. The clusters of serum elements in control were $\mathrm{Cr}$, $\mathrm{Se}, \mathrm{Fe}, \mathrm{Cu}, \mathrm{Zn}, \mathrm{Mg}$, and $\mathrm{Ca}$; clusters of serum elements in DPN group were $\mathrm{Cr}$, $\mathrm{Se}, \mathrm{Fe} ; \mathrm{Cu} ; \mathrm{Zn} ; \mathrm{Mg}$, and $\mathrm{Ca}$. Urinary elements in control were $\mathrm{Cr}, \mathrm{Fe}, \mathrm{Cu}$; $\mathrm{Ca}, \mathrm{Se}, \mathrm{Mg}$, and $\mathrm{Zn}$; urinary elements in DPN group are $\mathrm{Mg}, \mathrm{Ca}, \mathrm{Fe}, \mathrm{Zn}, \mathrm{Cu}, \mathrm{Cr}$, and $\mathrm{Se}$, respectively. It is obvious that serum $\mathrm{Cr}$, $\mathrm{Se}$, and $\mathrm{Fe}$ were clustered in both two groups. Association of $\mathrm{Mg}$ and $\mathrm{Ca}$ both in serum and urine of the DPN group were closer whereas serum $\mathrm{Cu}$ was weakly related to other elements, the same as what urinary $\mathrm{Cr}$ and $\mathrm{Se}$ were with the other.
Fig. 1 Dendrogram from cluster analysis of trace elements in serum of control (a) and DPN group (b) showing their division into four to five clusters at 10 and the same as those in the urine of control (c) and DPN group (d), respectively. U, Urinary

\section{Factor Analysis of Elements in Serum and Urine in Control and DPN Group}

The first 3 eigenvalues-factors containing the most information of models-were extracted and described throughly in Fig. 2. Loadings, the correlation coefficient between each element and the primary 3 factors extracted, were shown in Table 3 . The value beyond 0.5 is interpreted as relatively strong relevance.

The levels of $\mathrm{Mg}, \mathrm{Ca}, \mathrm{Zn}$, and $\mathrm{Cr}$ in urine and serum $\mathrm{Cu}$ in the DPN group were significantly higher. Various experiments resulted differently, Zhu [63] found that elements in urine of the DPN group were lower than control while this was not quite accurate on multivariable analysis stating only $24 \mathrm{~h}$ urine volume was different between two groups. Gómez T [64] concluded that concentration of $\mathrm{Zn}$ and $\mathrm{Ca}$ in urine of T1D rats was higher than those of control. However, when they applied $24 \mathrm{~h}$ urine specimens, the conclusion was just the opposite. They believed that this phenomenon was due to $24 \mathrm{~h}$ urine volume discrepancy $(r>0.7, p<0.001)$. Therefore, to explore difference of urine elements more accurately, $24 \mathrm{~h}$ urine specimen should be optimal.

\section{Discussion}

\section{Alternation in Elements of Serum and Urine of Control and DPN Group}

Trace elements are emerging hotspots in the field of diabetes. With deepening of research and achievement transformation, new perspectives were provided for clarification of mechanism and treatment. There are clinical trials and experimental complementary therapies now.

In this experiment, serum $\mathrm{Mg}, \mathrm{Ca}, \mathrm{Zn}$, and $\mathrm{Cr}$ in the DPN group were significantly lower than those of control, which was consistent with the discoveries of our team [8,9] and other scholars [18, 25, 26]. $\mathrm{Mg}$ is considered to be an independent predictor of type 2 diabetes progression $[25,27$, 28] and its complications [8, 29, 30], and clinical experiments have confirmed that $\mathrm{Mg}$ supplementation can improve hyperglycemia, oxidative stress, and inflammatory response in diabetic patients [31]. Zhang [7] and other investigators [18, 32, 33] demonstrated that serum $\mathrm{Mg}$ was lower in patients with diabetes, and Zhang [7] found that Mg was associated with parameters reflecting nerve conduction efficacy in DPN patients [7]. It has been stated that diabetes is characterized with negative $\mathrm{Mg}$ balance [20], for reduced gastrointestinal 


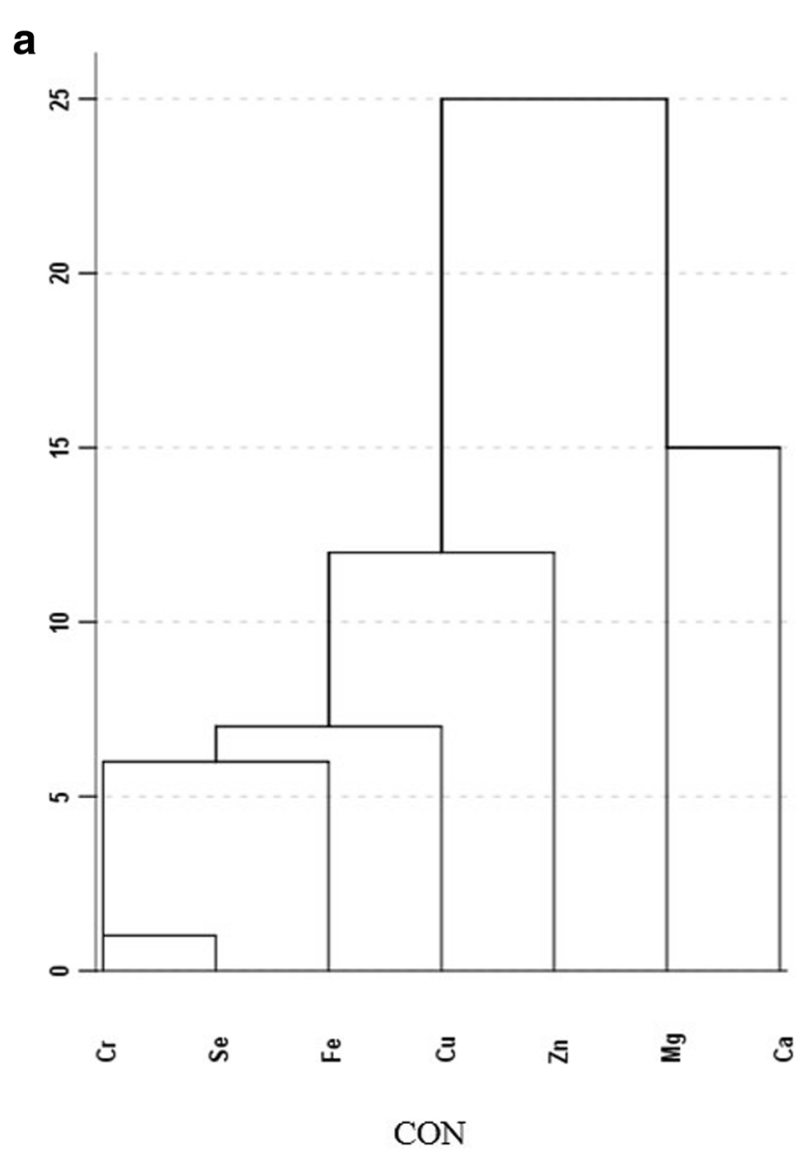

b
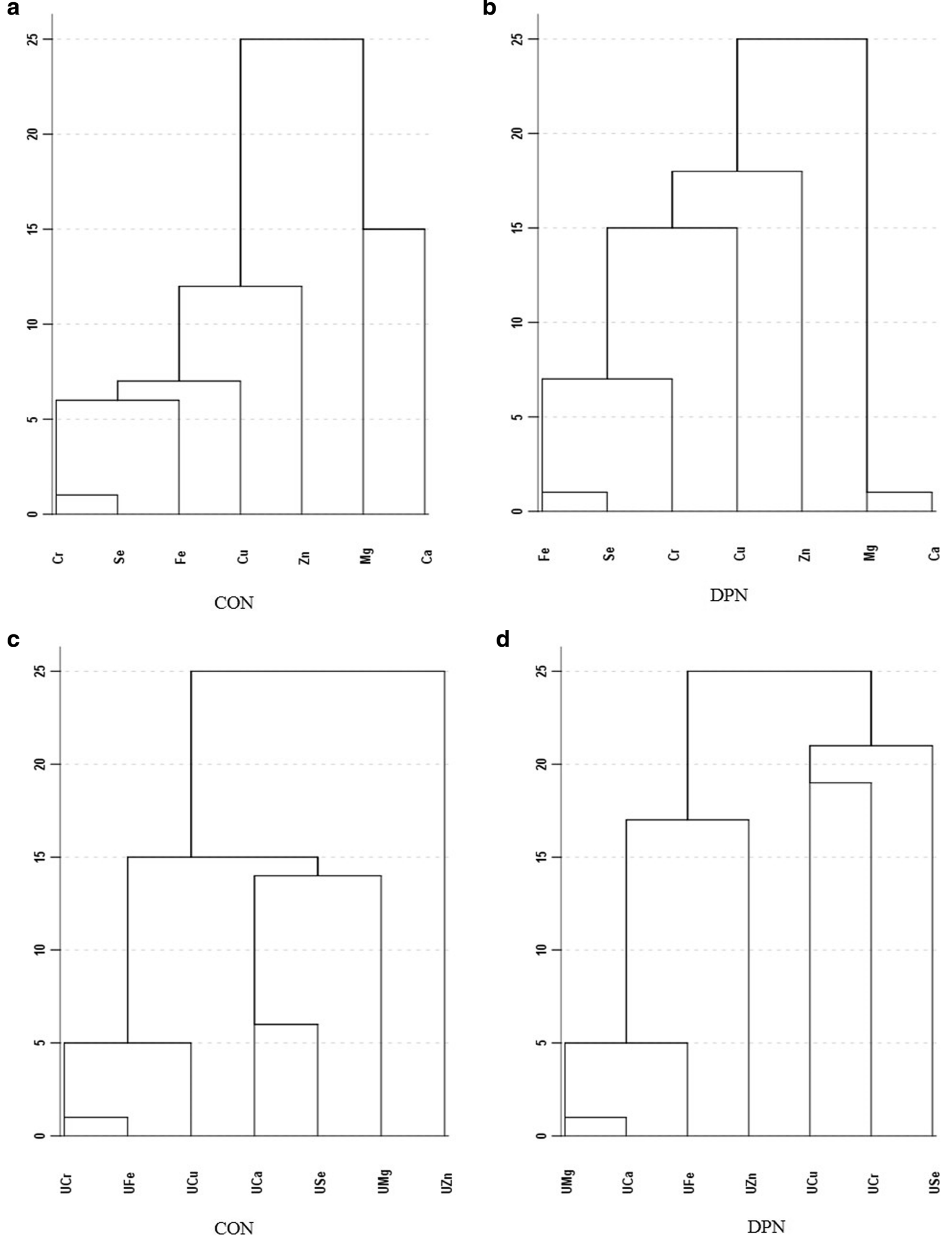
a

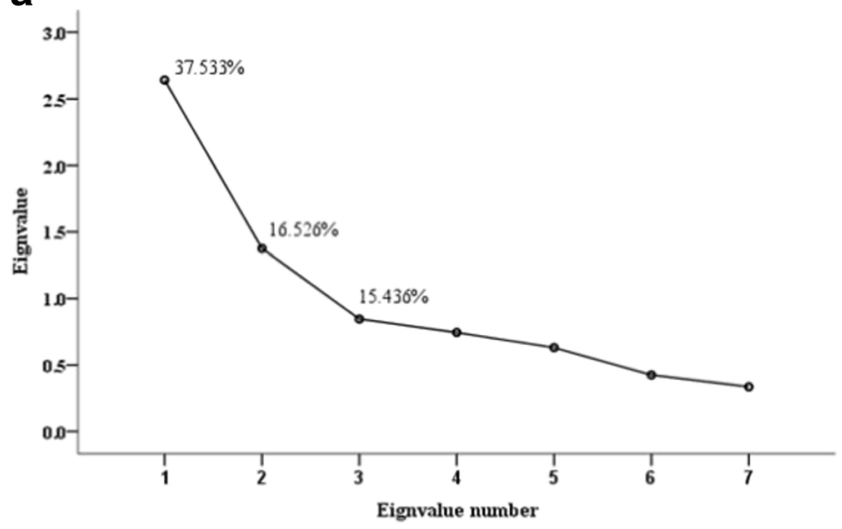

C

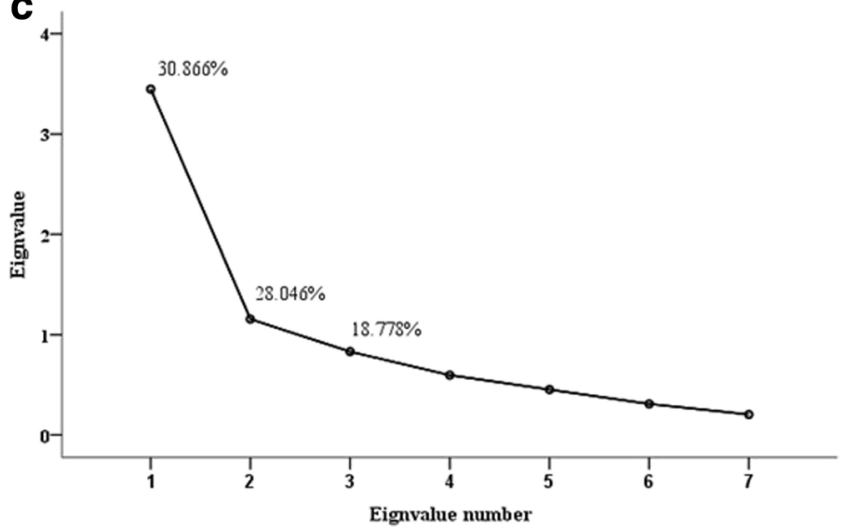

b

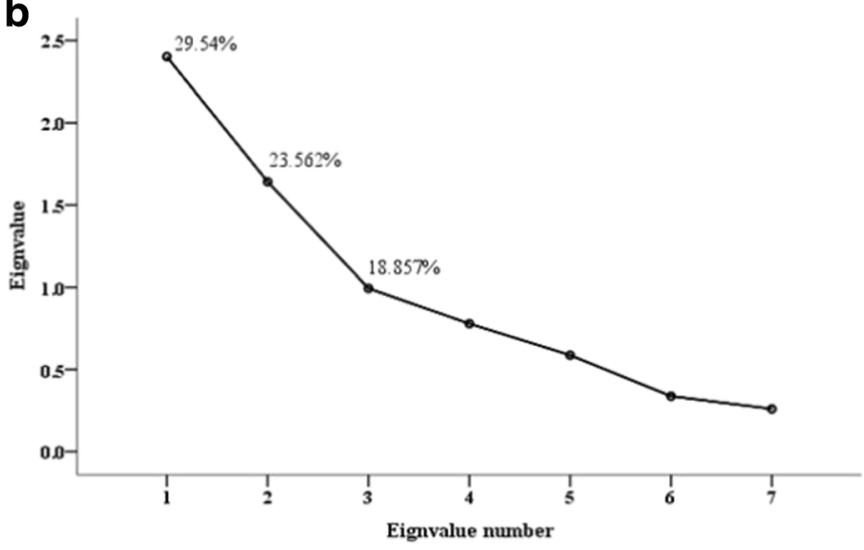

d

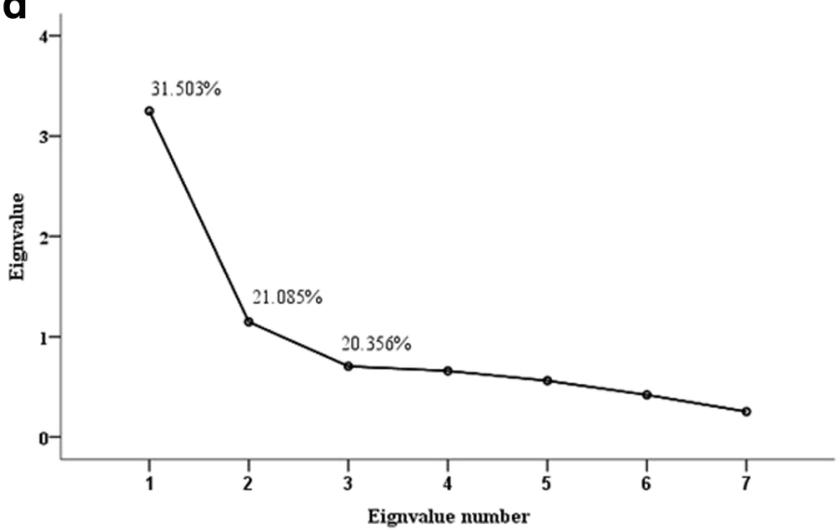

Fig. 2 Eigenvalues of the correlation matrix. The first three factors representing percentage of information in serum of control (a) and DPN group (b), the same as those in the urine of control (c) and DPN group (d), respectively

absorption [34], altered renal reabsorption [35], and redistribution caused by metabolic and/or pH disorders [35]. Though it's still controversial, certain basic and clinical trial have already witnessed that $\mathrm{Mg}$ supplementation improved diabetes. It might protect diabetic nephropathy [36] by improving glycemic control [31] and repairing tubular injury [37] and exerting negative effect on insulin sensitivity in ELDerawi's [38] experiment. Our previous study found that serum $\mathrm{Ca}$ decreased under DPN [8]. Diabetes damage signaling of Ca in axons, which is the main reason leading to diabetic

Table 3 Loadings of variables on three principal components of elements in control and DPN patients

\begin{tabular}{|c|c|c|c|c|c|c|c|c|c|c|c|c|}
\hline \multirow[t]{3}{*}{ Element } & \multicolumn{6}{|l|}{$\mathrm{CON}$} & \multicolumn{6}{|l|}{ DPN } \\
\hline & \multicolumn{3}{|l|}{ Serum } & \multicolumn{3}{|l|}{ Urinary } & \multicolumn{3}{|l|}{ Serum } & \multicolumn{3}{|l|}{ Urinary } \\
\hline & $\mathrm{F} 1$ & $\mathrm{~F} 2$ & $\mathrm{~F} 3$ & $\mathrm{~F} 1$ & PC2 & PC3 & $\mathrm{PC} 1$ & PC2 & PC3 & PC1 & PC2 & PC3 \\
\hline $\mathrm{Mg}$ & 0.022 & 0.138 & 0.960 & 0.343 & 0.413 & 0.518 & -0.105 & 0.899 & 0.071 & 0.700 & 0.454 & 0.135 \\
\hline $\mathrm{Ca}$ & 0.074 & 0.939 & 0.141 & 0.338 & 0.783 & 0.130 & 0.175 & 0.903 & -0.076 & 0.896 & 0.170 & 0.088 \\
\hline $\mathrm{Cu}$ & 0.733 & 0.183 & 0.021 & 0.908 & 0.037 & 0.029 & 0.258 & -0.104 & 0.678 & 0.123 & 0.740 & 0.377 \\
\hline $\mathrm{Zn}$ & 0.595 & 0.095 & 0.103 & -0.017 & 0.078 & 0.946 & 0.047 & 0.092 & 0.822 & 0.350 & 0.744 & 0.030 \\
\hline $\mathrm{Cr}$ & 0.736 & -0.322 & 0.270 & 0.626 & 0.524 & 0.345 & 0.838 & 0.054 & -0.077 & -0.014 & 0.350 & 0.744 \\
\hline $\mathrm{Fe}$ & 0.728 & -0.321 & -0.221 & 0.843 & 0.300 & 0.050 & 0.790 & 0.051 & 0.297 & 0.833 & 0.134 & 0.158 \\
\hline $\mathrm{Se}$ & 0.812 & 0.082 & -0.076 & 0.047 & 0.899 & 0.112 & 0.794 & -0.030 & 0.283 & 0.282 & 0.014 & 0.823 \\
\hline Eigenvalue & 2.627 & 1.157 & 1.080 & 2.161 & 1.963 & 1.314 & 2.068 & 1.649 & 1.320 & 2.205 & 1.476 & 1.425 \\
\hline$\%$ of variance explained & 37.533 & 16.526 & 15.436 & 30.866 & 28.046 & 18.778 & 29.540 & 23.562 & 18.857 & 31.503 & 21.085 & 20.356 \\
\hline$\%$ cumulative variance & 37.533 & 54.058 & 69.495 & 30.866 & 58.912 & 77.690 & 29.540 & 53.101 & 71.959 & 31.503 & 52.588 & 72.994 \\
\hline
\end{tabular}

Significant correlation coefficients $(>0.05)$ are italicized. $F$ Factor 
neurodegeneration [39-41]. Disturbed homeostasis of $\mathrm{Ca}^{2+}$ in diabetic patients could have resulted from changed bone metabolism, altered dietary absorption, impaired organelle dysfunction [42], and endoplasmic reticulum stress [43, 44] of metabolic organs such as the liver and adipose tissue. Higher urinary $\mathrm{Mg}$ correlates positively with urinary $\mathrm{Ca}$ [45], resulting from decreased renal tubular reabsorption [8]. $\mathrm{Ca}^{2+}$-containing supplementation has been deemed effective in clinical experiments to improve diabetic nephropathy [46], bone metabolic reverse [47], and cardiovascular diseases [48]. Observations have been substantiated by intervention that relevant supplementation-improved glycated hemoglobin in T1D patients $[49,50]$. Low serum $\mathrm{Zn}$ is seen in diabetes patients $[9,26]$, and Luo's [26] experiment showed that low serum $\mathrm{Zn}$ was associated with diabetic microvascular complications. $\mathrm{Zn}$ is a protective element, acting as an antioxidant by protecting sulfhydryl groups of various proteins and enzymes against free radical damage [51]. Its reduction was on account of eliminated effect of antioxidation and free radicals scavenging, noticing oxidation stress is one of significant mechanisms of DPN [52]. Zinc supplementation could prevent disease progression to diabetes by controlling blood glucose and insulin resistance while improving $\beta$-cell function [53]. Diabetic patients are with lower serum $\mathrm{Cr}$ [54, 55], while many trials have confirmed that $\mathrm{Cr}$ supplementation altered high glucose status $[56,57]$ and slowed progression of complications [57-59]. The mechanism could be Cr directly bound with insulin and prolonged its duration of action plus antioxidative stress role [56]. Low $\mathrm{Cr}$ may attribute to increased loss plus decreased absorption [60], in that metabolic control system in T1D actually need additional $\mathrm{Cr}$ [61] while it cannot be utilized and eliminated through urination [62]. Elements concentration in urine may also be affected by high urinary excretion [9], osmotic change, etc.

\section{Cluster Analysis and Factor Analysis of Serum and Urine Elements in Control and DPN Patients}

Cluster analysis is an exploratory method. The concept is to classify variables on characteristics so that the ones in the same category own the highest homogeneity as possible, whereas the different categories present the highest possible heterogeneity. The more intuitive explanation is that indicators are divided apart according to "distance". Choice of specific algorithms depends mostly on variable type, sample size, and research purpose [65]. Factor analysis is a mean of solving multivariate association. As a simplification method, it classifies potential "categories" by decomposing the original information and combines them into several independent "factors" that reflect the overall information to represent several types of highly correlated variables. This method preserves the original variable information as much as possible and could be applied to explore the intrinsic structure of variables. The two methods seem to have opposite principles, but they actually complete each other in a certain sense.

Elements relate to each other in the human body, which has been proven by previous researches $[8,9,20]$ and studies [10]. Factor analysis becomes applicable consequently. In summary, this study refers to Badran's [10] research on selection of statistical models and feasibility for such subject.

The results showed that serum $\mathrm{Cr}$, $\mathrm{Se}$, and $\mathrm{Fe}$ were clustered in both groups and association of $\mathrm{Mg}$ and $\mathrm{Ca}$ in serum and urine of the DPN group was stronger. Similarly, factor analysis stated serum $\mathrm{Cr}$, Se, and Fe were all correlated with factor 1, indicating that the three elements do relate to each other under both healthy and diseased status. That might be due to their common effects on insulin sensitivity [66-68] and oxidative stress $[14,69]$. Serum $\mathrm{Mg}$ was strongly associated with factor 2 in the DPN group comparing to its relationship with factor 3 in control. That demonstrated $\mathrm{Mg}$ had greater influence for the DPN group, which might reveal as significant elevation of $\mathrm{Mg}$ under diabetic status [7, 8]. Table 3 presented the obvious correlation of serum Mg and Ca in DPN [8, 20] strongly interacted with factor 3 , from the fact that product of $\mathrm{Mg}$ and $\mathrm{Ca}$ is quite fixed [8,20]. Urinary Se correlated with $\mathrm{Mg}$ and Ca negatively under DPN, we had not found any logical evidence but supposed that this might due to the peroxidation state of diabetes based on the characteristic function of these antioxidant elements. Though positively correlated with factor 3, serum, $\mathrm{Cu}$ was less important for the DPN group. Badran [10] assumed that $\mathrm{Cu}$ was negatively associated with factor 1 and attributed that factor to metabolic discrepancy. The above conclusions had been considered for a specific population.

We had not observed the tendency to change of urinary elements. However, there were few likely studies indeed. To our knowledge, this is the first study to use multivariable statistical methods for discussion of urinary elements in diabetes. Although there are still some defects and objective obstacles, the whole design was unique. The results were obscure due to many possible factors. One is no reliable evidence for the selection of random urine specimens. However, different classification and factors of urine elements of two groups were extremely unlike, and the causes we supposed were as follows: impact on excretion rate due to multiple forms of various elements, charge, molecular weight and other components, etc. and great variation of physical and chemical alternation of urine. Palmer [70] believed that ion disorders in diabetic patients might be attributed to osmotic fluid transfer caused by hyperglycemia as well as fluid shortage because of diuresis, referring to permeability effecting ions' flow.

Limitations of these experiments are the following: (1) Because of small sample size, there still remains uncertainty as to the results in the present study. (2) We use random urine in the study. However, $24 \mathrm{~h}$ urine specimen is a better choice. (3) Factor analysis may be weak for nonlinear model as the 
relationship could be nonlinear. (4) Practical theories on urinary elements remain unclear. However, the results are logical and consistent with current clinical trials. (5) Concentration of elements in urine may be determined by factors as dietary, absorption efficacy and kidney function, etc.

\section{Conclusion}

Multivariate statistical methods could reduce the number of variables, integrate information, and explore their internal correlation. Cluster analysis's principal is the homogeneity of variables. Factor analysis decomposes original information and recombines into factors representing several related variables. Our study confirmed that serum elements altered significantly in DPN against those of healthy population with reasonable mechanisms. Transformation medicine could be applied into clarification and treatment of disease. It is suggested that the future research and regimens adopt grouping model, that is putting similar elements together in a big picture or discussing relationship within them separately.

Funding The data cited from the laboratories of authors were supported in part by grants from the National Science Foundation of China (no. 81501839, to Dr. Qi Zhou), Scientific and Technological "13th FiveYear Plan" Project of Jilin Provincial Department of Education (no. JJKH20180214KJ, to Dr. Qi Zhou.), Jilin Province Health and Technology Innovation Development Program (no. 2017 J071, to Dr. Jiancheng $\mathrm{Xu}$, and the Jilin Science and Technology Development Program (no. 20170623092TC-09, to Dr. Jiancheng Xu; no. $20160101091 \mathrm{JC}$, to Dr. Jiancheng Xu; no. 20150414039GH, to Dr. Jiancheng $\mathrm{Xu}$; no. 20190304110YY to Dr. Jiancheng Xu), The First Hospital Translational Funding for Scientific \&Technological Achievements (no. JDYYZH-1902002 to Dr. Jiancheng Xu) and Norman Bethune Program of Jilin University (no. 2012223, to Dr. Jiancheng $\mathrm{Xu}$ ).

\section{Compliance with Ethical Standards}

Conflict of Interest The authors declare that they have no conflict of interest.

Open Access This article is distributed under the terms of the Creative Commons Attribution 4.0 International License (http:// creativecommons.org/licenses/by/4.0/), which permits unrestricted use, distribution, and reproduction in any medium, provided you give appropriate credit to the original author(s) and the source, provide a link to the Creative Commons license, and indicate if changes were made.

\section{References}

1. Pop-Busui R, Boulton AJ, Feldman EL, Bril V, Freeman R, Malik RA, Sosenko JM, Ziegler D (2017) Diabetic neuropathy: a position statement by the American Diabetes Association. Diabetes Care 40(1):136-154. https://doi.org/10.2337/dc16-2042
2. Pop-Busui R, Lu J, Brooks MM, Albert S, Althouse AD, Escobedo J, Green J, Palumbo P, Perkins BA, Whitehouse F, Jones TL, Group BDS (2013) Impact of glycemic control strategies on the progression of diabetic peripheral neuropathy in the bypass angioplasty revascularization investigation 2 diabetes (BARI 2D) cohort. Diabetes Care 36(10):3208-3215. https://doi.org/10.2337/dc130012

3. Peltier A, Goutman SA, Callaghan BC (2014) Painful diabetic neuropathy. BMJ 348:g1799. https://doi.org/10.1136/bmj.g1799

4. Sifuentes-Franco S, Pacheco-Moises FP, Rodriguez-Carrizalez AD, Miranda-Diaz AG (2017) The role of oxidative stress, mitochondrial function, and autophagy in diabetic polyneuropathy. J Diabetes Res 2017:1673081. https://doi.org/10.1155/2017/ 1673081

5. Stino AM, Smith AG (2017) Peripheral neuropathy in prediabetes and the metabolic syndrome. J Diabetes Investig 8(5):646-655. https://doi.org/10.1111/jdi.12650

6. Ennis SL, Galea MP, O'Neal DN, Dodson MJ (2016) Peripheral neuropathy in the hands of people with diabetes mellitus. Diabetes Res Clin Pract 119:23-31. https://doi.org/10.1016/j. diabres.2016.06.010

7. Zhang Q, Ji L, Zheng H, Li Q, Xiong Q, Sun W, Zhu X, Li Y, Lu B, Liu X, Zhang S (2018) Low serum phosphate and magnesium levels are associated with peripheral neuropathy in patients with type 2 diabetes mellitus. Diabetes Res Clin Pract 146:1-7. https:// doi.org/10.1016/j.diabres.2018.09.015

8. Xu J, Xu W, Yao H, Sun W, Zhou Q, Cai L (2013) Associations of serum and urinary magnesium with the pre-diabetes, diabetes and diabetic complications in the Chinese northeast population. PLoS One 8(2):e56750. https://doi.org/10.1371/journal.pone.0056750

9. Xu J, Zhou Q, Liu G, Tan Y, Cai L (2013) Analysis of serum and urinal copper and zinc in Chinese northeast population with the prediabetes or diabetes with and without complications. Oxidative Med Cell Longev 2013:635214. https://doi.org/10.1155/2013/ 635214

10. Badran M, Morsy R, Soliman H, Elnimr T (2016) Assessment of trace elements levels in patients with type 2 diabetes using multivariate statistical analysis. J Trace Elem Med Biol 33:114-119. https://doi.org/10.1016/j.jtemb.2015.10.006

11. Pittas AG, Lau J, Hu FB, Dawson-Hughes B (2007) The role of vitamin $\mathrm{D}$ and calcium in type 2 diabetes. A systematic review and meta-analysis. J Clin Endocrinol Metab 92(6):2017-2029. https:// doi.org/10.1210/jc.2007-0298

12. Volpe SL (2008) Magnesium, the metabolic syndrome, insulin resistance, and type 2 diabetes mellitus. Crit Rev Food Sci Nutr 48(3): 293-300. https://doi.org/10.1080/10408390701326235

13. Wilson JG, Lindquist JH, Grambow SC, Crook ED, Maher JF (2003) Potential role of increased iron stores in diabetes. Am J Med Sci 325(6):332-339

14. Burk RF (2002) Selenium, an antioxidant nutrient. Nutr Clin Care 5(2):75-79

15. Wolide AD, Zawdie B, Alemayehu T, Tadesse S (2016) Evaluation of serum ferritin and some metal elements in type 2 diabetes mellitus patients: comparative cross-sectional study. Diabetes Metab Syndr Obes 9:417-424. https://doi.org/10.2147/DMSO. S120326

16. Tang X, Shay NF (2001) Zinc has an insulin-like effect on glucose transport mediated by phosphoinositol-3-kinase and Akt in 3T3-L1 fibroblasts and adipocytes. J Nutr 131(5):1414-1420. https://doi. org $/ 10.1093 / \mathrm{jn} / 131.5 .1414$

17. Siddiqui K, Bawazeer N, Joy SS (2014) Variation in macro and trace elements in progression of type 2 diabetes. ScientificWorldJournal 2014:461591. https://doi.org/10.1155/ 2014/461591

18. Chu C, Zhao W, Zhang Y, Li L, Lu J, Jiang L, Wang C, Jia W (2016) Low serum magnesium levels are associated with impaired 
peripheral nerve function in type 2 diabetic patients. Sci Rep 6: 32623. https://doi.org/10.1038/srep32623

19. Association CD (2009) Diagnostic criteria for diabetic peripheral neuropathy. Chin J Diabetes 17(8):638-640

20. Zhou Q, Guo W, Jia Y, Xu J (2018) Effect of 4-phenylbutyric acid and tauroursodeoxycholic acid on magnesium and calcium metabolism in streptozocin-induced type 1 diabetic mice. Biol Trace Elem Res 189:501-510. https://doi.org/10.1007/s12011-018-1494-8

21. Zhou Q, Wang D, Xu J, Chi B (2016) Effect of tauroursodeoxycholic acid and 4-phenylbutyric acid on metabolism of copper and zinc in type 1 diabetic mice model. Biol Trace Elem Res 170(2):348-356. https://doi.org/10.1007/s12011-0150474-5

22. Aldenderfer MS, Blashfield RK (1984) Cluster analysis. Paper series on qualitative applications in the social sciences, Beverly Hills

23. Vermunt JK, Magidson J (2002) Latent gold 4.0 User's Guide. Statistical Innovations, Belmont

24. Everitt BS, Landau S, Leese M, Stahl D (2011) Cluster analysis, 5th edn. John Wiley \& Sons Ltd, West Sussex

25. Lorenzo C, Hanley AJ, Rewers MJ, Haffner SM (2014) Calcium and phosphate concentrations and future development of type 2 diabetes: the insulin resistance atherosclerosis study. Diabetologia 57(7):1366-1374. https://doi.org/10.1007/s00125-014-3241-9

26. Luo YY, Zhao J, Han XY, Zhou XH, Wu J, Ji LN (2015) Relationship between serum zinc level and microvascular complications in patients with type 2 diabetes. Chin Med J 128(24):32763282. https://doi.org/10.4103/0366-6999.171357

27. Dong JY, Xun P, He K, Qin LQ (2011) Magnesium intake and risk of type 2 diabetes: meta-analysis of prospective cohort studies. Diabetes Care 34(9):2116-2122. https://doi.org/10.2337/dc110518

28. Hruby A, Meigs JB, O'Donnell CJ, Jacques PF, McKeown NM (2014) Higher magnesium intake reduces risk of impaired glucose and insulin metabolism and progression from prediabetes to diabetes in middle-aged americans. Diabetes Care 37(2):419-427. https://doi.org/10.2337/dc13-1397

29. Chen H, Li X, Yue R, Ren X, Zhang X, Ni A (2013) The effects of diabetes mellitus and diabetic nephropathy on bone and mineral metabolism in T2DM patients. Diabetes Res Clin Pract 100(2): 272-276. https://doi.org/10.1016/j.diabres.2013.03.007

30. Lu J, Gu Y, Guo M, Chen P, Wang H, Yu X (2016) Serum magnesium concentration is inversely associated with albuminuria and retinopathy among patients with diabetes. J Diabetes Res 2016: 1260141. https://doi.org/10.1155/2016/1260141

31. Rodriguez-Moran M, Guerrero-Romero F (2003) Oral magnesium supplementation improves insulin sensitivity and metabolic control in type 2 diabetic subjects: a randomized double-blind controlled trial. Diabetes Care 26(4):1147-1152

32. Hyassat D, Al Sitri E, Batieha A, El-Khateeb M, Ajlouni K (2014) Prevalence of hypomagnesaemia among obese type 2 diabetic patients attending the National Center for diabetes, endocrinology and genetics (NCDEG). Int J Endocrinol Metab 12(3):e17796. https:// doi.org/10.5812/ijem.17796

33. Zhang Y, Li Q, Xin Y, Lv W, Ge C (2018) Association between serum magnesium and common complications of diabetes mellitus. Technol Health Care 26(S1):379-387. https://doi.org/10.3233/ THC-174702

34. Pham PC, Pham PM, Pham PT (2012) Patients with diabetes mellitus type 2 and hypomagnesemia may have enhanced glomerular filtration via hypocalcemia. Clin Nephrol 78(6):442-448. https://doi.org/10.5414/CN107525

35. Mooren FC (2015) Magnesium and disturbances in carbohydrate metabolism. Diabetes Obes Metab 17(9):813-823. https://doi.org/ 10.1111/dom. 12492

36. Sakaguchi Y, Shoji T, Hayashi T, Suzuki A, Shimizu M, Mitsumoto K, Kawabata H, Niihata K, Okada N, Isaka Y, Rakugi H,
Tsubakihara Y (2012) Hypomagnesemia in type 2 diabetic nephropathy: a novel predictor of end-stage renal disease. Diabetes Care 35(7):1591-1597. https://doi.org/10.2337/dc12-0226

37. Matsuzaki H, Ohdachi J, Fuchigami M, Masuyama R, Uehara M, Nakamura K, Suzuki K (2002) Changes in N-acetyl-beta-Dglucosaminidase activity in the urine and urinary albumin excretion in magnesium deficient rats. Biosci Biotechnol Biochem 66(1): 192-194. https://doi.org/10.1271/bbb.66.192

38. WA EL, Naser IA, Taleb MH, Abutair AS (2018) The effects of oral magnesium supplementation on glycemic response among type 2 diabetes patients. Nutrients 11(1). https://doi.org/10.3390/ nu11010044

39. Zochodne DW, Ramji N, Toth C (2008) Neuronal targeting in diabetes mellitus: a story of sensory neurons and motor neurons. Neuroscientist 14(4):311-318. https://doi.org/10.1177/ 1073858408316175

40. Zherebitskaya E, Akude E, Smith DR, Fernyhough P (2009) Development of selective axonopathy in adult sensory neurons isolated from diabetic rats: role of glucose-induced oxidative stress. Diabetes 58(6):1356-1364. https://doi.org/10.2337/db09-0034

41. Chowdhury SK, Smith DR, Fernyhough P (2013) The role of aberrant mitochondrial bioenergetics in diabetic neuropathy. Neurobiol Dis 51:56-65. https://doi.org/10.1016/j.nbd.2012.03. 016

42. Arruda AP, Hotamisligil GS (2015) Calcium homeostasis and organelle function in the pathogenesis of obesity and diabetes. Cell Metab 22(3):381-397. https://doi.org/10.1016/j.cmet.2015.06.010

43. Xu J, Wang G, Wang Y, Liu Q, Xu W, Tan Y, Cai L (2009) Diabetes- and angiotensin II-induced cardiac endoplasmic reticulum stress and cell death: metallothionein protection. J Cell Mol Med 13(8A):1499-1512. https://doi.org/10.1111/j.1582-4934. 2009.00833.x

44. Xu J, Zhou Q, Xu W, Cai L (2012) Endoplasmic reticulum stress and diabetic cardiomyopathy. Exp Diabetes Res 2012:827971. https://doi.org/10.1155/2012/827971

45. Olukoga AO, Adewoye HO, Erasumus RT (1989) Renal excretion of magnesium and calcium in diabetes mellitus. Cent Afr J Med 35(4):378-383

46. Ghadiri-Anari A, Mozafari Z, Gholami S, Khodaei SA, Aboutorabi-Zarchi M, Sepehri F, Nadjarzade A, Rahmanian M, Namiranian N (2019) Dose vitamin D supplementations improve peripheral diabetic neuropathy? A before-after clinical trial. Diabetes Metab Syndr 13(1):890-893. https://doi.org/10.1016/j. dsx.2018.12.014

47. Larsen AU, Grimnes G, Jorde R (2018) The effect of high-dose vitamin D3 supplementation on bone mineral density in subjects with prediabetes. Osteoporos Int 29(1):171-180. https://doi.org/10. 1007/s00198-017-4222-x

48. Dimova R, Tankova T, Chakarova N (2017) Vitamin D in the spectrum of prediabetes and cardiovascular autonomic dysfunction. J Nutr 147(9):1607-1615. https://doi.org/10.3945/jn.117.250209

49. Aljabri KS, Bokhari SA, Khan MJ (2010) Glycemic changes after vitamin D supplementation in patients with type 1 diabetes mellitus and vitamin D deficiency. Ann Saudi Med 30(6):454-458. https:// doi.org/10.4103/0256-4947.72265

50. Hafez M, Hassan M, Musa N, Abdel Atty S, Azim SA (2017) Vitamin D status in Egyptian children with type 1 diabetes and the role of vitamin D replacement in glycemic control. J Pediatr Endocrinol Metab 30(4):389-394. https://doi.org/10.1515/jpem2016-0292

51. DiSilvestro RA (2000) Zinc in relation to diabetes and oxidative disease. J Nutr 130(5S Suppl):1509S-1511S. https://doi.org/10. 1093/jn/130.5.1509S

52. Farvid MS, Homayouni F, Amiri Z, Adelmanesh F (2011) Improving neuropathy scores in type 2 diabetic patients using 
micronutrients supplementation. Diabetes Res Clin Pract 93(1):8694. https://doi.org/10.1016/j.diabres.2011.03.016

53. Ranasinghe P, Wathurapatha WS, Galappatthy P, Katulanda P, Jayawardena R, Constantine GR (2018) Zinc supplementation in prediabetes: a randomized double-blind placebo-controlled clinical trial. J Diabetes 10(5):386-397. https://doi.org/10.1111/1753-0407. 12621

54. Hajra B, Orakzai BA, Faryal U, Hassan M, Rasheed S, Wazir S (2016) Insulin sensitivity to trace metals (chromium, manganese) in type 2 diabetic patients and non diabetic individuals. J Ayub Med Coll Abbottabad 28(3):534-536

55. Makhlough A, Makhlough M, Shokrzadeh M, Mohammadian M, Sedighi O, Faghihan M (2015) Comparing the levels of trace elements in patients with diabetic nephropathy and healthy individuals. Nephrourol Mon 7(4):e28576. https://doi.org/10.5812/ numonthly. 28576

56. Ulas M, Orhan C, Tuzcu M, Ozercan IH, Sahin N, Gencoglu H, Komorowski JR, Sahin K (2015) Anti-diabetic potential of chromium histidinate in diabetic retinopathy rats. BMC Complement Altern Med 15:16. https://doi.org/10.1186/s12906-015-0537-3

57. Sahin K, Tuzcu M, Orhan C, Ali S, Sahin N, Gencoglu H, Ozkan Y, Hayirli A, Gozel N, Komorowski JR (2013) Chromium modulates expressions of neuronal plasticity markers and glial fibrillary acidic proteins in hypoglycemia-induced brain injury. Life Sci 93(25-26): 1039-1048. https://doi.org/10.1016/j.lfs.2013.10.009

58. Vincent JB (2004) Recent developments in the biochemistry of chromium(III). Biol Trace Elem Res 99(1-3):1-16. https://doi. org/10.1385/BTER:99:1-3:001

59. Sahin K, Onderci M, Tuzcu M, Ustundag B, Cikim G, Ozercan IH, Sriramoju V, Juturu V, Komorowski JR (2007) Effect of chromium on carbohydrate and lipid metabolism in a rat model of type 2 diabetes mellitus: the fat-fed, streptozotocin-treated rat. Metabolism 56(9):1233-1240. https://doi.org/10.1016/j.metabol. 2007.04.021

60. Cunningham JJ (1998) Micronutrients as nutriceutical interventions in diabetes mellitus. J Am Coll Nutr 17(1):7-10

61. Lin CC, Huang YL (2015) Chromium, zinc and magnesium status in type 1 diabetes. Curr Opin Clin Nutr Metab Care 18(6):588-592. https://doi.org/10.1097/MCO.0000000000000225

62. Nsonwu ACUC, Etukudo MH et al (2006) Glycemic control and serum and urine levels of chromium and magnesium in diabetics in Calabar, Nigeria. Pak J Nutrit 5:75-78
63. Zhu W, Mai Z, Qin J, Duan X, Liu Y, Zhao Z, Yuan J, Wan SP, Zeng $\mathrm{G}$ (2016) Difference in 24-hour urine composition between diabetic and non-diabetic adults without nephrolithiasis. PLoS One 11(2): e0150006. https://doi.org/10.1371/journal.pone.0150006

64. Gomez T, Bequer L, Mollineda A, Molina JL, Alvarez A, Lavastida M, Clapes S (2017) Concentration of zinc, copper, Iron, calcium, and magnesium in the serum, tissues, and urine of streptozotocininduced mild diabetic rat model. Biol Trace Elem Res 179(2):237246. https://doi.org/10.1007/s12011-017-0962-x

65. Hofstetter H, Dusseldorp E, van Empelen P, Paulussen TW (2014) A primer on the use of cluster analysis or factor analysis to assess co-occurrence of risk behaviors. Prev Med 67:141-146. https://doi. org/10.1016/j.ypmed.2014.07.007

66. Saiyed ZM, Lugo JP (2016) Impact of chromium dinicocysteinate supplementation on inflammation, oxidative stress, and insulin resistance in type 2 diabetic subjects: an exploratory analysis of a randomized, double-blind, placebo-controlled study. Food Nutr Res 60:31762. https://doi.org/10.3402/fnr.v60.31762

67. Yadav C, Manjrekar PA, Agarwal A, Ahmad A, Hegde A, Srikantiah RM (2017) Association of serum selenium, zinc and magnesium levels with glycaemic indices and insulin resistance in pre-diabetes: a cross-sectional study from South India. Biol Trace Elem Res 175(1):65-71. https://doi.org/10.1007/s12011016-0766-4

68. Fargion S, Dongiovanni P, Guzzo A, Colombo S, Valenti L, Fracanzani AL (2005) Iron and insulin resistance. Aliment Pharmacol Ther 22(Suppl 2):61-63. https://doi.org/10.1111/j. 1365-2036.2005.02599.x

69. Gao W, Li X, Gao Z, Li H (2014) Iron increases diabetes-induced kidney injury and oxidative stress in rats. Biol Trace Elem Res 160(3):368-375. https://doi.org/10.1007/s12011-014-0021-9

70. Palmer BF, Clegg DJ (2015) Electrolyte and acid-base disturbances in patients with diabetes mellitus. N Engl J Med 373(6):548-559. https://doi.org/10.1056/NEJMra1503102

Publisher's Note Springer Nature remains neutral with regard to jurisdictional claims in published maps and institutional affiliations. 